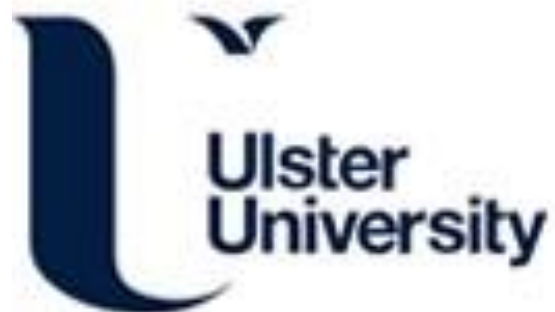

\section{EU democracy promotion in Turkey: funding NGOs, funding conflict?}

Ketola, M. (2011). EU democracy promotion in Turkey: funding NGOs, funding conflict? The International Journal of Human Rights, 15(6), 787-800. https://doi.org/10.1080/13642987.2011.572551

Link to publication record in Ulster University Research Portal

\section{Published in:}

The International Journal of Human Rights

Publication Status:

Published (in print/issue): 01/08/2011

DOI:

10.1080/13642987.2011.572551

\section{Document Version}

Author Accepted version

\section{General rights}

Copyright for the publications made accessible via Ulster University's Research Portal is retained by the author(s) and / or other copyright owners and it is a condition of accessing these publications that users recognise and abide by the legal requirements associated with these rights.

\section{Take down policy}

The Research Portal is Ulster University's institutional repository that provides access to Ulster's research outputs. Every effort has been made to ensure that content in the Research Portal does not infringe any person's rights, or applicable UK laws. If you discover content in the Research Portal that you believe breaches copyright or violates any law, please contact pure-support@ulster.ac.uk. 


\title{
EU democracy promotion in Turkey: funding NGOs, funding conflict?
}

\author{
Markus Ketola* \\ Department of Social Policy, London School of Economics and Political Science, \\ London, $U K$
}

Funding nongovernmental organisations (NGOs) to encourage democratisation features prominently on the EU's policy agenda for accession countries. The rationale for EU funding to NGOs communicated through policy documents suggests such interests are largely due to the salience of liberal democratic rhetoric, premised on supporting liberal individualism and respect for human rights. By looking at the situation in Turkey, this article argues that the success of such an approach is contingent on how well it corresponds with the reality of civil society relations in the recipients' context. In cases where such a correlation between policy and context does not exist, donor funding may lead to further divisions between groups in civil society, and even fuel the differences that exist between various groups.

Key words: democracy; civil society; NGOs; Turkey; EU accession

\section{Introduction}

Endeavours at democratisation and rights-based reforms are at the heart of Turkey's accession process to join the European Union (EU). The so-called Copenhagen criteria require EU accession countries to have acquired certain standards in terms of democratic institutions, human rights and the protection of minorities. In line with Turkey's European aspirations, the Turkish government adopted no less than nine constitutional amendment packages between 1999 and 2004, greatly improving the legal framework in support of democracy. ${ }^{1}$ In addition to the role played by politicians and other state actors, NGOs have played an important role in the change processes that Turkey has been undertaking as part of its accession negotiations.

\footnotetext{
*Email: m.ketola@1se.ac.uk
} 
This article examines how useful the principles of liberal democracy, upon which the EU approach is based, are as guideposts for effective policy. By applying for membership Turkey has committed itself to adhere to the values the EU upholds, suggesting that these values make sensible criteria for policy formulation. Despite the clear logic behind such an approach, does it provide the most effective means of bringing about the changes required by the accession process? How responsive will local actors, such as NGOs, be to policies that have been framed in such a way?

The argument of this article is that an external policy approach based on liberal democratic principles is likely to be less effective, because the proposed ideals do not correspond to local experience. The policy goals remain external to the social context where they intend to have an impact. In such a scenario the resulting policy is less likely to engage civil society actors with the planned change processes. Given the incongruence between policy and reality, some NGOs actively resist the policy that the EU pursues. In other instances, local actors operate and relate to each other in ways that do not correspond with EU expectations. EU strategy of funding civil society as an avenue for democratisation can thus misconstrue the realities of Turkish civil society, and it is important to recognise these limitations for any policy outcomes.

The article sets off with an outline of the logic behind strategies employed by international organisations such as the EU to promote liberal democracy through a focus on civil society, and the problems that have been associated with such an approach. Considering in turn both the character of civil society in Turkey, and the policies that the EU has employed in relation to Turkish civil society, the article then offers an account of some NGO experiences. These NGO examples highlight the different ways in which EU funding is approached, as well as the difficulties EU policy may have in relating to the aspects of Turkish civil society that are not consistent with this policy approach.

\section{Liberal democratic logic to develop civil society - and its critics}

How civil society is commonly conceptualised among donors traces its roots to the development of civil society in Europe and North America, emphasising the liberal democratic aspects of Western civil society. The writings of Georg Friedrich Hegel are one influential source of ideas for the Western understanding of civil society. Individuality is at the centre of what civil society means to Hegel, as civil society is a 
contestational space where competing interests struggle for prominence. It is the particular needs and wants of individuals that govern their behaviour in civil society. Self-seeking individuals aiming to fulfil their private needs are the building blocks of civil society. ${ }^{2}$ However, if our actions were governed solely by the instinct to have our own needs fulfilled with complete disregard for the needs of others, our society would not survive. ${ }^{3}$ Thus, the particular, selfish behaviour in civil society is cushioned by universal conventions and customs that place constrains on what is regarded as acceptable behaviour. The attainment of self-interest is conditioned by universality, leading to a system of complete interdependence between individuals. The happiness of one is dependent on this connection with universal interests. In essence, the existence of civil society is an expression of this balance between the private and universal interests.

It is worth noting that Hegel's writings on civil society also highlight the vulnerability, fragility and contingent nature of civil society. People are not innately public-spirited, but nevertheless agree to cooperate because this ensures that a broader set of their needs and interests will be met. There is a constant ebb and flow being played out between individual and public interests. Hegel goes as far as describing civil society as the 'battlefield where everyone's individual private interests meet everyone else's'. ${ }^{4}$ As John Keane points out, Hegel does not treat Western civil society as a naturally existing phenomena, but rather as a product of a particular historical process. ${ }^{5}$ For Hegel civil society emerged from the idiosyncrasies of the modern commercial system as it evolved in Europe in the $18^{\text {th }}$ century. The way in which civil society evolves in a different context is therefore contingent on the unique way in which the system of needs negotiates a balance between the different interests groups that exist. There is no blueprint, or at least the Western experience offers nothing of the kind.

What is therefore important is the content of the universal - the sociocultural context in which individuals operate - as this defines the limits and opportunities for what civil society can achieve.

Another key figure to consider here is Alexis de Tocqueville, a $19^{\text {th }}$ century thinker, because his writings on civil society have been influential in defining how civil society is understood in the West today. His book, Democracy in America, persuasively describes associationalism as a bulwark against despotism. In his scholarship, de Tocqueville was particularly concerned with the consequences of 
spreading equality under democratic conditions, which, if left unattended, would increase the threat of despotism. The rise in the equality of social conditions will make it possible for citizens to acquire sufficient material possessions to satisfy their own needs without help from others. What follows is an individuation of citizens as they become less dependent on their community for support; people will have a reduced interest in the affairs of the community, becoming socially less active and withdrawing from a role in the administration of local affairs. ${ }^{6}$ The emerging gap in local administration will be filled by central government, and this accumulation of power in the hands of the central government contributes to the development of a despotic state.

Local associations are de Tocqueville's answer to manage what he terms as undesirable and undemocratic consequences. These associations should be given responsibility over local affairs, which bear relevance to the everyday welfare of the community and are thus likely to engage and interest citizens. There is thus an added value in freely formed associations. These would not only protect against the 'dark side' of individualism, but provide a way for citizens to take initiative and organise themselves around issues that are important. These associational activities emerge organically from the actions of citizens and serve to influence government decisionmaking.

These arguments made by de Tocqueville that weld together individualism, associations and democracy resonate with more recent interpretations. A similar tone is found, for example, in Robert Putnam's work. In Making Democracy Work, the argument put forth suggests that associational networks have a direct effect on government performance. In this study of Italy's regions, identical regional governments displayed higher levels of effectiveness where civic engagement was stronger. Voter turnout, newspaper readership, membership in choral societies and football clubs were among the indicators of civic engagement. ${ }^{7}$ The quality of this civic community is what determines the quality of democracy, argues Putnam, for this type of activity fosters 'habits of cooperation and public-spiritedness' that develop the civic skills required for participation in public life, which in turn 'inculcates democratic habits'.

The liberal democratic logic expressed above is also reflected in the formulation of donor policy. NGOs, through the kinds of activities they engage in, are able to strengthen civil society as well as improve democratic processes. ${ }^{9}$ Civil 
society is deemed important for sustaining the democratic pulse of modern nation states, defending against abuses of state power. Importantly, a certain threshold of civil and political rights remains a prerequisite for this scenario to unfold, as this is what enables NGOs to project societal demands onto the state. Because of this, any support given to civil society groups is frequently framed in terms of rights-based initiatives that make a contribution to the democratisation processes.

Whether this view offers a normative model to be applied more generally, however, is debatable. From a liberal democratic perspective, civil society is seen as a bulwark against the excesses of the state, and the number of civil society organisations (CSOs) is taken as an indicator of democratic development. Such logic has certainly been reflected in the strategies adopted by international donor agencies, including the EU, who have been inclined to see the support they give to civil society as an instrument of democratic development. Jude Howell and Jenny Pearce, for example, label these developments as the 'Americanization of the debate', arguing that despite rich and varied experiences around the globe, the view of the United States and its donor agencies has grown to be dominant in civil society discourse. ${ }^{10}$ The donors see their aims as constituting a neutral, value free approach, forming a template ready for use in any context. NGOs act as functionaries of democracy that are able to increase citizen participation in activities that hold the state to account. What is more, these organisations are also seen to be bipartisan advocates of neutral discussion, moving away from traditional boundaries of political ideology. ${ }^{11}$ Donors have thus opted for solutions that are de-politicised and probably out of tune with political realities. The dominance of the Western interpretation of state-civil society relations continues to undervalue the local, already existing civil society where it does not fit the liberal democratic mould. ${ }^{12}$

The dominant meanings of civil society that tie in with notions of liberal individualism are therefore likely to suffer from a lack of contextual relevance in nonWestern contexts. This puzzle poses a particular challenge in contexts where prevailing cultural differences tend to emphasise the distinctions among groups. As Iris Marion Young has argued, the ideal of liberal individualism tends to promote an assimilationist model that is unlikely to reflect people's experiences. Liberal individualism challenges the notion of difference that arises from group identity, and any discrimination that is based on group privileges. According to liberal individualism, therefore, citizens should be viewed only as individuals, not as 
members of groups. ${ }^{13}$ The trouble with such an interpretation, observes Young, is that it ignores other more legitimate reasons for preserving group identities. It is more sensible to consider individuals as part of a particular social context, defined by the community within which they live. As long as groups are not linked to oppression or exclusion of other groups, group identity can be an important element of how individual identity becomes rooted within a community. Pushing for a policy that favours liberal individualism in a context where such an experience is far removed from the reality of social relations may end up isolating groups further. As long as it does not lead to oppression and exclusion, and individuals are at liberty to choose their membership, group-based identities are not wrong in principle.

The argument put forth here is that groups within civil society tend to struggle to find a balance between policy that is based largely on a liberal individualistic model, and their own experience that is at least partly tied in with particular group identities. Whilst EU policy rightly pursues aims that are anchored in principles of universal human rights and democracy, the broader implications of this policy can leave NGOs in a difficult position in terms of making sense of their organisational role and identity. In a Hegelian sense, the sociocultural values that constitute the universal are not commensurate in the European and Turkish cases. Thus, the application of a Western political ideal encourages policies and practices that fail to resonate with the local context and may thereby not offer the best strategy for success. In the Turkish case, this lack of fit contributes to feelings of insecurity among NGOs, advancing both antagonistic reactions towards the EU project and conflictual relations between NGOs. EU policy on civil society development in Turkey could benefit from not being defined negatively, that is, in opposition to the state, or, externally, on the bases of a particular Western trajectory of civil society development, but positively, by being rooted in communal expressions of civil society and in local traditions and practices.

\section{Ambivalences of Civil Society in Turkey}

Although Turkey has displayed a deep commitment to reform in recent years, the EU continues to challenge Turkey on the limitations imposed on rights and entitlements. Such demands are often made in an abstract sense, articulated as principles that ought to be adhered to, rather than applying them in ways that are contextually relevant. For example, the EU has been conspicuously silent during the recent debates on the issue 
of whether the ban on wearing headscarves in universities violates the right to education. It highlights the gap that exists between the policy demands made as part of the accession process, framed in terms of broad principles, and what is realistically achievable.

One key contextual limitation not fully accounted for by EU civil society policy is the narrowness of Turkish civil society as a space where public debate can occur. Historically, the operational space allotted to civil society has been rather limited in Turkey. For one, Turkish national identity was inspired by notions of secular Turkishness, forming a rather narrow overlap with existing identities - ethnic and religious identities in particular. ${ }^{14}$ In the 1930s, the key principles of 'Kemalism' were formulated, as a way of defining a hegemonic discourse that would ensure the success of the nation building process begun by Mustafa Kemal Atatürk in the 1920s. Subsequently, the secular state and its governing discourse was defined through a series of binaries, such as 'progressive-conservative'; 'modern-traditional'; 'progressbackward'. ${ }^{15}$ These ideas defining the secular state set the agenda as well as the parameters for the kind of activism that civil society actors could engage in, at least in any formal capacity.

A key period in the development of Turkish civil society followed the 1980 military coup, as a variety of voices began gradually to find legitimate space within civil society. The years leading up to the coup were marked by escalating political instability and violence as movements at the extreme ends of the political Left and Right duelled. Recognizing the need to quell the Marxist and Fascist movements and to stabilise social relations, the military junta looked for allies in other areas of society, initiating a decade-long transition from 'confrontation to tolerance'. ${ }^{16}$ Through the relative autonomisation of economic activities, political groups and different identities, an autonomous civil society began to develop, shifting the focus increasingly from state to society. Instead of questioning the legitimacy of the ruling regime, the debate focused on particular policies, where women, environmentalists, gays and lesbians have been particularly successful in making new demands through the new civil society spaces that were available. ${ }^{17}$ The greatest beneficiaries from the policy of increased tolerance have been Islamic civil society groups. From these developments, multiple identities have surfaced that today are widely represented in civil society, forming the bases for the various claims that are being made by civil society activists. 
However, whilst an increasing number of voices are now able to assert their claims through civil society, and the policy of cultural homogeneity of the past has been challenged, the nature of the debate has not changed. This debate is still conducted in a binary-seeking, essentialist spirit. ${ }^{18}$ The emergent particular discourses should all constitute a part of an array of discourses coexisting in a pluralist civil society. Instead, the Islamist discourse, for example, has tended towards the formation of a new singularity, a new 'totalizing discourse' that aims to replace the universal discourse of secular Turkishness with another. ${ }^{19}$ Similarly, through the 1980 s and 1990s, civil society organisations were founded with the active aim of defending the Kemalist project from its detractors. ${ }^{20}$ Consequently, civil society has emerged as the new battle ground where the debate tends to retain an essentialist and uncompromising nature, with Kemalist and Islamic groups leading the charge.

In Turkey, the post 1980s era has witnessed dual trajectories of development. Civil society has been both autonomised and essentialised. From the point of view of a liberal democratic political discourse this conclusion points to both opportunities and shortcomings. On the one hand, civil society has become a pluralist force, effectively representing various minority interests. On the other hand, civil society within that plurality remains vulnerable to being appropriated for non-democratic purposes. Civil society acts to justify the hegemonic and non-democratic claims made by particular points of view. There indeed has been a structural change out of which an autonomous societal sphere has emerged, but we need to be more careful in identifying the content of this sphere. Being located outside of the state is not sufficient; we still need to be attuned to the normative and ideological premises behind civil society actors, before it is possible to understand how civil society organisations might impact democratisation.

The debate surrounding the issue of the headscarf illustrates this. On the one side, the debate frames the right to wear a headscarf as an issue of human rights; by banning access to universities for veiled women violates the equality of access to education. Accordingly, each citizen ought to have the same educational entitlement regardless of their religious disposition or chosen dress code. ${ }^{21}$ On the other side of the debate, these claims are interpreted as a challenge to the secular nature of the Turkish state. These demands are seen merely the first step on a road to establishing an Islamic state in Turkey. Headscarves are also taken as a symbol of conservative, traditional and backward values that are incompatible with a modern nation state 
aspiring for EU membership. ${ }^{22}$ The EU response to this debate has been somewhat unclear. In 2004, the European Court of Human Rights sided with the secular side of the debate in deciding that the headscarf ban did not violate the right to education. ${ }^{23}$ Since then, and particularly during the recent public debate, the EU has refrained from taking sides or commenting on the headscarf ban. At the same time, the broader accession rhetoric from the EU makes explicit references to the insufficient standards of democracy and respect for rights, yet not voicing opinions on any specific issue. Such mixed messages are illustrative of the difficulties that arise when applying the democratic principles of rights in a particular country context where this leads to a problematisation of the local socio-political situation. Any viable solution ought to correspond with the experiences of how individuals make sense of their own social context.

\section{EU civil society policy in the Turkish context}

Democratic principles nevertheless remain a central justification for EU involvement in civil society activity in Turkey. The approach suggests that EU policy purports a liberal democratic logic, where civil society functions as a bulwark against the excesses of the state and as the means to enable individuals to exercise their democratic voice outside elections. It also reveals a technical approach to civil society development, where NGOs are viewed as vehicles for delivering certain types of projects that may not be entirely congruent with the socio-cultural context in which they operate. The principles of democracy and human rights are among the fundamental values upon which the European Union has been founded, and remain influential guideposts in enlargement policy. ${ }^{24}$ In the context of EU accession, these ideas surface primarily as part of the Copenhagen criteria, which requires that any candidate country must achieve stable institutions that guarantee democracy, rule of law, human rights and respect for minorities prior to accession. The reasons for funding civil society - NGOs in particular - are framed in terms of their contribution to furthering the causes of liberty, democracy and human rights.

Some observers remain rather critical of EU civil society policy and what it offers to beneficiaries, because policy is guided by specific ideas about what civil society should look like in the recipient countries. Viewed from this perspective, EU policy can be seen to represent a hegemony of a particular world-view that promotes certain values through EU development policy. ${ }^{25}$ To this end, where the partner NGOs 
are selected on the bases of their compatibility with the EU's mission, they are more likely to legitimise the EU's idea of what civil society ought to be like. This is because any successful NGO applicant to EU funding programmes is likely to operate in a manner familiar to the EU, easily slotting into the bureaucratic routine of projects. By reinforcing the segment of civil society that already understands the EU way of doing things, EU actions are quietly transforming civil society in its own image. Whilst it is possible to identify similar characteristics in EU civil society policy in Turkey, where the EU influences the development of civil society through its selection of partner NGOs, the events are unlikely to play themselves out quite so one-sidedly. When policies are not considerate of the social context in which they are implemented, this is likely to generate a reaction among the local actors that undermines the success of the said policies. This leads to the emergence of critical voices that resist what they view as policies imposing an external agenda.

EU project rationales also demonstrate how EU policy is justified on the bases of its contribution to democratisation. One project that demonstrated this and is analysed here is entitled 'Strengthening Freedom of Association for Further Development of Civil Society'. ${ }^{26}$ The rationale for the project is drawn from the requirements of the first pillar of the Copenhagen criteria. The overall objective is stated as 'enhanced participatory democracy through strengthened NGOs', to be achieved by increasing NGO capacity for 'networking, voluntary work, national and international dialogue in Turkey, ${ }^{27}$ The activities are broken down into three components. First, capacity building for NGOs through a "comprehensive training programme covering different aspects of organizations' management and the needs of the civil society sector'. Second, raising awareness of civil society among NGOs, the media, public authorities and the general public by establishing a communication centre and by promoting the NGO sector through seminars, conferences and publications. The third component offers micro-grants to NGOs in order to facilitate dialogue and communication with their counterparts in the EU. ${ }^{28}$ The methods employed for enhancing democratisation and strengthening NGOs draw clearly from the liberal democratic course of thought. The project aims at creating greater space for NGO activity and generating greater capacity for NGOs to peruse this space. How NGOs operate or the content of this activism is not questioned; there is a sense of inherent goodness in the work of NGOs. 
Since the start of the Turkish accession negotiations in late 2004, the EU has been recalibrating its civil society funding programme to better align this with the pragmatic needs of the accession process. The emphasis on civil society funding is shifting from support for human rights-based initiatives to supporting the needs of the accession process. A programme on 'civil society dialogue' has been the new policy innovation. This idea was first proposed in October 2004 by the European Commission and endorsed by the European Council in December 2004. In June 2005, a communication entitled 'Civil Society Dialogue between the EU and Candidate Countries' was published by the European Commission that spells out the nature of the policy shift. The document draws on the lessons learnt from previous rounds of enlargement and was in fact written with Turkey's accession negotiations specifically in mind. The emergence of civil society dialogue represents an important policy shift that further centralises the role of civil society in the pre-accession process. For example, the communication earmarks as much as $8-10 \%$ of Turkey's total annual pre-accession financial assistance to civil society related activities. The document opines that:
any future enlargement of the EU needs to be supported by a strong, deep and sustained dialogue [...] this would help to bridge the information gap, achieve better mutual knowledge and bring citizens and different cultures, political and economic systems closer together, thus ensuring a stronger awareness of the opportunities as well as challenges of future accessions [...] civil society should play the most important role in this dialogue. ${ }^{29}$

This policy of dialogue reflects both continuity and change. What is new about this process is the harnessing of civil society activism as an explicit instrument of accession. The aim of the dialogue is to make sure that both Turkish and EU citizens are sufficiently informed about the other, ensuring a smoother enlargement process. The more time the two sides spend together, the more ideological cleavages can be bridged, and differences of opinion ironed out prior to accession. NGOs are seen as key agents within this process of dialogue, asked to facilitate the accession process by way of establishing a channel of communication between the two sides of the accession negotiations. This is an important current objective of the negotiations, and NGOs have been utilised in its achievement. However, previous themes of democratisation and human rights also remain important. Civil society dialogue, by increasing the participation of civil society in political, cultural and economic 
development, is described as developing a lively and vibrant civil society in candidate countries, which is key to the consolidation of human rights and democracy, in line with the political criteria for accession. Thus, the activities involved in projects that engage in civil society dialogue still contribute to democratisation efforts. In other words, this suggests that, regardless of the content of NGO activism, by virtue of it taking place in civil society, this activism has a democratising effect. This is indicative, once again, of the liberal democratic agenda that informs this policy.

The Turkish Secretariat General for EU Affairs (EUSG) has developed a grants programme to reflect these changing priorities. Under the 'Promotion of the Civil Society Dialogue between Turkey and the European Union' it has committed to awarding grants amounting to $€ 19,3$ million in total. The grants are divided across four separate schemes: Towns and Municipalities ( $€ 5$ million), Professional Organisations ( $€ 3$ million), Universities ( $€ 9,3$ million) and Youth Initiatives for Dialogue ( $€ 2$ million). In total, 119 projects have been awarded grants, and in each a Turkish organisation involved has partnered with an organisation from either an EU member state or another candidate country. ${ }^{30}$ With a focus on the details of one of these grant schemes, the Youth Initiatives for Dialogue grants programme?, the following analysis addresses three questions. Who has access to such grant funding? What are the objectives and how are these to be achieved? What implications does this have for the eventual outcomes of the programme?

The funding is granted for projects that are between $€ 30,000$ and $€ 100,000$ in value, which imposes limitations on potential candidates for the grants. The project funding covers, at most, 90 per cent of the total costs of the project. In other words, in order to qualify for a grant the recipient must have at least $€ 3000$ in cash from another non-EU source. Furthermore, given the relatively high value of the grants, it is highly likely that any successful applicant will have had previous experience of managing a funded project. The requirement for alternate sources of funding acts as a similar limitation; a successful candidate is required to have the additional capacity to look for two sources of funding at the same time. The expectation to partner with a European NGO imposes other criteria, as candidate NGOs need to perform the required outreach activities to identify potential partners. All of these factors are likely to channel the funding towards the large, urban, established entities that are able to manage these processes successfully. 
The grant scheme has the following two objectives: '1) to promote mutually beneficial and sustainable relationships between youth initiatives in Turkey and in EU Member States and candidate countries and promote dialogue between the Turkish and EU counterparts by addressing the opportunities and challenges of enlargement; 2) to encourage exchange of knowledge and best practices on planning and implementation of EU policies'. ${ }^{31}$ Whilst the first objective is entirely within the scope of the civil society dialogue process as it has been described above, the second key objective is directly relevant to the pragmatic side of the civil society dialogue process. It also points to the role EU envisages for Turkish civil society more generally, as facilitators of the process of policy implementation that the EU accession process requires. These objectives are realised through activities that include 'information campaigns and events (seminars, conferences, internet forums) in the Republic of Turkey and/or in EU member states that target involvement of wider community groups - NGOs, business sectors etc.' and 'actions and events for promotion of the project and for ensuring the visibility of EU support and the idea of civil society dialogue'. ${ }^{32}$ These are compulsory activities, suggesting that very particular outcomes are supported by this grant facility. Civil society is not seen as a source of diversity, or as a source of new ways of doing things, but rather as a partner than can be asked to deliver specific outcomes that suit the needs of the EU and the accession process.

I argue that these projects represent a relatively narrow agenda for civil society activity, aspiring for a particular type of change within civil society by particular groups of NGOs. Whilst this may be an expected occurrence within the accession process, it is less certain whether this offers a good fit in relation to the reality and social context of civil society activity in Turkey. How realistic are these expectations and how likely are the proposed outcomes? In the following section, I offer an assessment of the opportunities and shortcomings of EU policy in the Turkish context by reflecting on certain experiences of Turkish NGOs.

\section{The NGO experience: participation, resistance, conflict and EU policy}

The availability of funding and the policy objectives set out by the donors is but one side of the equation, however, as it is equally important to understand the variety of reactions that availability of funding solicits from the potential NGO recipients. Once in contact with the local context, the liberal democratic premise of EU policies is 
vulnerable to losing relevance among the potential recipient NGOs. The appropriateness of EU policy is here considered from two angles. First, NGO attitudes towards the policy are explored. In the second section, the discussion delves into the character of relationships between NGOs to illustrate how civil society activity unfolds in practice and how debates are conceptualised within the Turkish civil societal space. Positive and negative responses as well as the motivations behind them are outlined with a view to suggesting that the availability of EU funding in itself creates divisions among the NGOs.

For one group of NGOs the introduction of EU funding has clearly been a positive experience. The impact of external assistance has been enabling in two important ways. First of all, funding makes a contribution to the internal capacity of NGOs to get things done. For Turkish advocacy NGOs in particular, it has been difficult to access funding from domestic sources, so it is here that EU funds, in their current form, are at their most congruent with local needs. ${ }^{33}$ The activities of advocacy NGOs are frequently focused on influencing government policy, and their discourse in doing so is framed within a rights-based rhetoric. Here, EU funding policy feeds directly into the NGOs' core activities, such as those of disseminating ideas through publications and conferences, as well as helping NGOs to increase their media exposure. The process of translating ideas into concrete actions has been streamlined, and external assistance has become a short cut to achieving the immediate aims that previously required a great deal of individual effort. ${ }^{34}$ The experience of partaking in EU funded projects also offers organisations a chance to learn about project management, providing NGOs with the wherewithal to apply successfully for future projects also. ${ }^{35}$ The second enabling effect of EU external assistance comes in the form of helping to change domestic perceptions about advocacy work. For many among the Turkish public, NGO advocacy continues to evoke images of troublemaking rather than an attempt to engage in a constructive dialogue with government. ${ }^{36}$ By offering these NGOs funding, the EU offers assurances that their work is legitimate and worthwhile, which in turn has improved the public image of NGOs. NGOs gain a label, a recognition that their work is valuable. In these ways, EU support can lead to both capacity and legitimacy gains for local NGOs.

Other NGOs, however, consciously steer clear and avoid EU funding. Such choice is in part based on what the NGO perceives its sources of legitimacy to be, and 
whether support from the EU would enhance or undermine this. External funding compromises their independence. For them, foreign institutions such as the EU have a particular agenda they wish to implement, and NGOs are being asked to help in this process. ${ }^{37}$ The funding is therefore viewed as not being neutral; there is an agenda behind it that spills over into an attempt to control NGO behaviour. Whilst politically many such NGOs lean to the right, this is not to say that they are not also progressive. For example, a number of women's NGOs have opposed the proposals to allow female students to attend university wearing headscarves, whilst also being at the

forefront of pushing through groundbreaking reforms with regard to gender equality. ${ }^{38}$ The stance these NGOs adopt in relation to EU funding is reflective of a broader scepticism and weariness towards the EU accession process. The refusal to accept EU funding contributes to the organisational identity of an NGO. The resistance to EU funding is viewed as a source of integrity, as an outward sign of keeping true to the values an NGO upholds as an organisation. Undertaking funded projects is seen as accepting someone else's agenda as your own, compromising the mission of the organisation. The agenda would be hijacked by the priorities dictated by the funding process. Another reason for NGOs not to participate in the EU funding process derives from a pure lack of organisational capacity. Lack of knowledge about the funding process, insufficient foreign language skills, inability to cope with the technical detail of EU funded projects all mean that many NGOs simply feel that EU funded projects are simply too onerous to pursue. ${ }^{39}$

These two salient strategies illustrate a more general point of how EU policies can generate various responses within civil society. These responses are defined by the sociocultural context and how EU policy is interpreted by it. It is therefore possible to argue that the outcomes of EU policy are uncertain, and contingent on the reaction of civil society. Furthermore, this shows how EU policy can generate or highlight group differences within the recipient civil society possibly leading to further conflict.

\section{Relationships between NGOs}

The opportunities and challenges of EU funding discussed above can be defined further by looking at how Turkish NGOs engage with each other in the context of advocacy campaigns. The women's movement, for example, has been involved in very successful advocacy campaigns framed around gender rights. At the same time 
there exist clear differences between groups that follow the existing ideological fault line. These observations resonate strongly with the suggestion made earlier that Turkish civil society simultaneously experiences autonomisation and essentialisation, explaining the somewhat paradoxical conclusion that NGOs are able to forge broad advocacy campaigns amidst (thus far) irreconcilable ideological differences.

Two successful policy advocacy campaigns in particular have led to the women's movement being regarded a success story of NGO advocacy in Turkey, able to fulfill the aims set by the EU for its civil society funding. Significantly, these campaigns expressed a sincere solidarity between various women's NGOs, bridging the secular-Islamic divide. Ideological and political differences were cast aside for the purpose of achieving lasting structural change. In 2001, the new Turkish Civil Code was adopted. This was a result of two decades of tireless advocacy by the women's movement that culminated in an energetic lobbying campaign on the eve of the final decision. The new Civil Code abolished the position of the husband as the formally recognized head of the family and bestowed women with new legal rights in divorce. Encouraged by this success, the women's movement refocused its efforts on a new campaign to reform the Turkish Penal Code. The new Penal Code, adopted in 2004, represented another milestone on the road towards gender equality in Turkey. No longer is sexual violence viewed as a crime against society but as a crime against the individual; rape within marriage is now considered a crime; and rapists are no longer able to marry their victims as a way of escaping punishment, for example. In all, over thirty recommendations made by the women's lobby group were adopted in the final law. ${ }^{40}$ Women's advocacy delivered significant changes to these policies.

However, for all their successes, the two campaigns were not devoid of tensions and differences. Despite a general consensus on the issues the women's NGOs were campaigning for, the accomplishment was framed through identity-based debates that led to conflictual relations between the organisations. Islamic and secular NGOs in particular were unable to put aside their differences. During the campaign on Penal Code reform the two sides were unable to reach an agreement on the content of their proposals. The Islamic groups did not agree with the demand that all references to 'morality', 'chastity' and 'honour' should be removed from their proposal, because doing so would contradict their religious commitment. ${ }^{41}$ In the end such demands remained in the proposal. Islamic groups in turn expressed their dissatisfaction by not attending the meetings or taking part in the lobbying efforts at parliament on the days 
when these issues were being debated.

In the slipstream of the successes of previous advocacy platforms, in the spring of 2007 women's NGOs organised a new platform in opposition to the government's proposal for social security reform. Dissatisfied with how insensitive the proposal was to women's concerns, they arranged a series of protest marches, with the aim of persuading the government to amend the proposed reform package. ${ }^{42}$ Unlike the previous campaigns on Penal and Civil Code reform, the mood of the entire campaign was shrouded in identity-based political claims. The secular women's NGOs saw this as an opportunity to protest against the government at large. The governing Justice and Development party (Adayet ve Kalkinma Partisi, AKP) possesses a genealogy that links it to the Islamic parties of the recent past, and thus the inadequate social security reform was used as evidence of how the AKP government adheres to a conservative, religious and backward understanding of social development, detrimental to modern, progressive women's rights. In so doing, an aspect of the campaign turned away from the universal language of women's rights towards a particular, essentialised agenda that not only challenged the government, but also created a reaction among Islamic NGOs to dissociate from the campaign. This was unfortunate, because both sides agreed with the initial policy position set by the platform: that government social security reform was inadequate in its consideration of gender concerns. As the religious undertones of the government became increasingly the focus of the campaign, the campaign focused increasingly on the religious identity of the government. However, the Islamic women's activists no longer felt that they could attend the protests, because they would have effectively ended up participating in protests that were aimed against their own identity. ${ }^{43}$

These examples demonstrate how civil society in Turkey can be described to having a dual character. On the one hand, women's groups are autonomised, evidenced by their firm stance against government policy. By packaging their concerns in the language of universal rights and gender equality, women's NGOs were able to garner broad support for their campaign and ultimately influence government policy. On the other hand, the debate gravitates towards essentialised positions, giving rise to factions and conflicts between groups. The allegiances and alliances within civil society display a combination of issue-based advocacy, interleaved with issues of identity politics that remain at the heart of the social debate in Turkey. 
The political tensions that exist within the women's movement - as well as within civil society at large - are keenly illustrated by these examples, and any evaluation of the potential impact of EU civil society funding should take these issues into consideration. Of all NGOs in Turkey, women's NGOs are regarded as the most successful in working together, but as we can see even here the relations are complex and potentially volatile. As illustrated in the previous section, EU support tends to be channeled towards a certain group of NGOs within civil society. In so doing, the EU positions itself rather awkwardly in relation to the existing political contestations within civil society, unwittingly fueling and reinforcing them whilst claiming to develop a more vibrant civil society that is contributing to democratisation.

\section{Conclusion}

I have argued that there is a disconnect between the aspirations of EU civil society policy and the reality of civil society activism in Turkey. EU policy conveys an approach that is informed by liberal democratic principles, and by harnessing its policy in support of these principles, it addresses the issue of group difference by promoting an individualistic conception which denies that group-based claims can be the basis for policy. This policy also assumes that civil society actors on the ground operate in a certain way that is closely aligned with the Tocquevillean view that regards civil society as a bastion of individual freedom and thus a central organ of democracy. On both accounts, this policy does not reflect the realities of Turkish civil society.

For some, such a disconnect between policy and reality is exactly the right approach. Through its membership application Turkey has made explicit its commitment to a variety of standards upheld by the EU, which contain certain criteria on democracy and human rights. One purpose of the accession negotiations is to problematise Turkey's democratic credentials and to instigate change where further developments are needed, and EU civil society policy is part of this process. Any disconnect, according to this logic, would be evidence of further work that is required for Turkey to comply with the accession criteria, rather than of a misconstrued policy.

However, the success of external policy processes, such as EU democracy promotion in Turkey through civil society funding, is at least partly dependent on how well such policies are received among the potential beneficiaries and how relevant the aims and objectives are to the everyday practices of civil society actors. Where EU 
civil society policy does not reflect such contextual appreciation, this policy is deemed to represent an external agenda that is being imposed upon Turkish civil society. This has generated strategies of resistance among NGOs, as certain organisations actively identify themselves in opposition to EU funding. Such resistance may not be focused on any particular policy, but rather against the methods of implementation and what EU policy is interpreted to represent. Importantly, it highlights the need for the local political context to be considered more carefully.

Group differences remain an important factor in determining how NGOs position themselves amidst social debates. Such discussions in Turkey tend to be framed in an essentialist manner, leaving a rather narrow space within civil society for collaboration and cooperation between NGOs that adhere to different values. The relations between Islamic and secular women's NGOs are a case in point; their actions are embedded in the political debates of the day, and guided by an ideological understanding of Turkish identity. This social context informs NGO behaviour also when participating in EU funded projects, and will play a part in determining the outcomes of such projects. NGOs do not constitute neutral and value-free vehicles for delivering objectives pertinent to the European project. The policy outcomes are thus grounded in the local character of civil society organisations, not in the content of policy documents.

\section{Notes}

1. Meltem Müftüler-Baç, 'Turkey's Political Reforms and the Impact of the European Union', South European Society and Politics 10, no. 1 (2005): 23.

2. Georg Wilhelm Friedrich Hegel, Hegel's Philosophy of right, trans. T.M. Knox (Oxford: Clarendon, 1952), section 182.

3. Hegel, Philosophy of right, section 185.

4. Hegel, Philosophy of right, section 289.

5. John Keane, Civil society : old images, new visions, (Cambridge, England: Polity Press, 1998).

6. Alexis de Tocqueville, Democracy in America, (Penguin, 1998), 206.

7. Robert Putnam, 'Bowling Alone: America's Declining Social Capital', Journal of Democracy 6, no. 1 (1995): 65-78; Robert Putnam, Robert Leonardi and Raffaella Nanetti, 'Making democracy work: civic traditions in modern Italy', (Princeton, J.J.: Princeton University Press, 1994).

8. Robert Putnam, Bowling alone : the collapse and revival of American community, (New York: Simon \& Schuster, 2000).

9. Claire Mercer, 'NGOs, civil society and democratization: a critical review of the literature', Progress in Development Studies 2, no. 1 (2002): 5-22.

10. Jude Howell and Jenny Pearce, Civil society \& development : a critical exploration, eds. Jude Howell and Jenny Pearce (Boulder, Colo.: Lynne Rienner Publishers, 2001b), 39-40.

11. Marina Ottaway and Thomas Carothers, Funding Virtue, (Washington: Brookings Institution Press, 2000).

12. Mercer, 'NGOs, civil society and democratization', 7. 
13. Iris Young, 'Together in Difference: Transforming the Logic of Group Political Conflict', in Principled positions : postmodernism and the rediscovery of value, ed. Judith Squires (London: Lawrence \& W., 1993), 121-50.

14. Günter Seufert, 'The Impact of National Discourses on Civil Society', in Civil Society in the Grip of Nationalism, eds. Stefan Yerasimos, Günter Seufert, and Karin Vorhoff (Orient-Institut, 2000), 25-47.

15. Fuat Keyman, 'On the Relation between Global Modernity and Nationalism: The Crisis of Hegemony and Rise of (Islamic) Identity in Turkey', New Perspectives on Turkey 13(1995): 93120.

16. Nilufer Göle, 'Toward an Autonomization of Politics and Civil Society', in Politics in the Third Turkish Republic, vol. 1, chap. 17, eds. Metin Heper and Ahmet Evin (Oxford: Westview Press, 1994), 213-222.

17. Ibid., 215.

18. Fuat Keyman, 'Global Modernity, Identity and Democracy: The Case of Turkey', in Redefining the Nation State and Citizen, eds. Günay Göksu Özdoğan and Gül Tokay (Istanbul: Eren, 2000).

19. Fuat Keyman, 'On the Relation between Global Modernity and Nationalism': 71.

20. Necmi Erdoğan, 'Kemalist Non-Governmental Organizations: Troubled Elites in Defence of a Sacred Heritage', in Civil Society in the Grip of Nationalism, ed. Stefan Yerasimos, Günter Seufert and Karin Vorhoff (Orient-Institut, 2000), 251-282.

21. Evren Çelik Wiltse, 'The Gordian Knot of Turkish Politics: Regulating Headscarf Use in Public', South European Society and Politics 13, no. 2 (2008): 195-215.

22. Hakan Seckinelgin, 'Civil society between the state and society: Turkish women with Muslim headscarves?', Critical Social Policy 26, no. 4 (2006): 748-69.

23. The European Court of Human Rights, Case of Leyla Sahin v. Turkey, No. 44774/98.

24. Christos Kassimeris and Lina Tsoumpanou, 'The Impact of the European Convention on the Protection of Human Rights and Fundamental Freedoms on Turkey's EU Candidacy', The International Journal of Human Rights 12, no. 3 (2008): 329-45.

25. Stephen R. Hurt, 'Co-operation and Coercion? The Cotonou Agreement between the European Union and ACP States and the End of the Lome Convention', Third World Quarterly 24, no. 1 (2003): 161-76.

26. European Commission, 'Strengthening Freedom of Association for Further Development of Civil Society', TR 04 01.04, 2004.

27. Ibid., 1.

28. Ibid., 5 .

29. European Union, Communication from the Commission to the Council, the European Parliament, the European Economic and Social Committee and the Committee of the Regions - Civil Society Dialogue between the EU and Candidate Countries, COM(2005) final, 2005,.2.

30. Civil Society Dialogue Project, 'What is the Civil Society Dialogue Project', website http://www.csdproject.net/web/AboutTheProgramme/tabid/54/language/en-US/Default.aspx (accessed 10 June 2009).

31. Secretariat General for EU Affairs, 'Youth Initiatives for Dialogue Grant Scheme', website http://www.abgs.gov.tr/index.php?p=5970\&l=2 (accessed June 10th, 2009).

32. Ibid.

33. Ali Carkoglu, 'Trends in Individual Giving and Foundation Practices in Turkey', in Philanthropy in Turkey: Citizens, Foundations and the Pursuit of Social Justice, ed. Filiz Bikmen and Rana Zincir (Istanbul: TUSEV, 2006).

34. Author interview with a civil society activist, Ankara, Turkey, April 1, 2008. (All interviews were conducted in confidentiality, the interviewee names being withheld by mutual agreement.)

35. Author interview with a civil society activist, Ankara, August 9, 2007.

36. Author interview with a civil society activist, Ankara, August 7, 2007.

37. Author interview with a civil society activist, Ankara, April 3, 2008.

38. Ela Anıl et al., Turkish Civil and Penal Code Reforms from a Gender Perspective: The Success of Two Nationwide Campaigns, (Istanbul: WWHR-New Ways, 2005).

39. Author interview with a civil society activist, Ankara, August 8, 2007.

40. Ela Anıl et al., Turkish Civil and Penal Code, p.25.

41. Author interview with a female activist, Ankara, April 03, 2008.

42. Author interview with a female activist, Istanbul, April 10, 2008.

43. Author interview with a female activist, Istanbul, April 14, 2008. 